\title{
Assessing space use by pre-breeding white-tailed eagles in the context of wind-energy development in Finland
}

\section{Balotari-Chiebao, Fabio}

2018-09

Balotari-Chiebao , F , Brommer , J E , Saurola , P , ljäs , A \& Laaksonen , T 2018 , ' Assessing space use by pre-breeding white-tailed eagles in the context of wind-energy development in Finland ', Landscape and Urban Planning , vol. 177 , pp. 251-258 . https://doi.org/10.1016/j.landurb

http://hdl.handle.net/10138/330258

https://doi.org/10.1016/j.landurbplan.2018.05.012

cc_by_nc_nd

acceptedVersion

Downloaded from Helda, University of Helsinki institutional repository.

This is an electronic reprint of the original article.

This reprint may differ from the original in pagination and typographic detail.

Please cite the original version. 
1 ABSTRACT - The expansion of wind energy over large areas may be accompanied by major 2 conflicts with birds, including birds of prey. Hence, it is desirable that the space use of species 3 known to be vulnerable to wind energy be assessed in light of current and future developments.

4 Here, we report on the large-scale dispersal movements of pre-breeding white-tailed eagles

5 (Haliaeetus albicilla) in Finland, where a currently modest wind-energy capacity is expected 6 to increase in the near future. We studied white-tailed eagle space use with a particular focus 7 on the potential for annual power production $(\mathrm{GWh})$ at specific locations, as estimated by the 8 Finnish Wind Atlas. Also, we aimed to detect a potential human-wildlife conflict by assessing 9 white-tailed eagle space use against the spatial distribution of existing and recently proposed 10 wind farms. We found that, despite visiting a large proportion of the country, the eagles stayed 11 primarily within coastal areas and islands, restricted to where human infrastructure was present 12 only at very small amounts. Because of the distribution of wind resources, such areas were 13 found to contain considerable potential for power production. The eagles visited most of the 14 areas targeted for wind-energy development. However, these areas did not coincide with a 15 higher-than-average eagle relocation frequency, suggesting that the existing and recently 16 proposed wind farms do not represent an elevated threat to dispersing eagles. Caution should 17 nevertheless be taken against interpreting that co-occurrence poses no threat at any given site, 18 as site selection is paramount to avoid conflicts with avian conservation.

19

20 Keywords: raptors, turbine, renewable energy, conservation, landscape ecology, land use 


\section{Introduction}

The use of wind energy is recognised as an important means to help reduce the consumption of fossil fuels, thereby contributing to the mitigation of climate change (Wiser et al. 2011). The wind industry continues to expand at a rapid pace, especially in Asia, Europe, and North America. In 2015, new wind energy installations accounted for nearly half of global electricity growth (Global Wind Energy Council, 2015).

Despite its benefits, wind energy can be detrimental to birds in terms of collision mortality, displacement, habitat loss, and barriers to movements (Drewitt and Langston 2006). As regards collision, comparisons with other man-made structures (e.g. buildings, communication towers, power lines) suggest the impact of wind turbines to be minor (Erickson et al., 2005; Loss, 2016). However, wind energy increases worldwide and concerns have been raised about development in areas inhabited by species of high conservation value. Large soaring raptors, together with e.g. swans, geese, ducks, waders and owls, appear to be at greatest risk of collision (Tosh et al. 2014). Golden eagles and other raptors have suffered high fatality rates at the Altamont Wind Resource Area in the USA (Smallwood and Thelander 2008), and griffon vultures in southern Spain (de Lucas et al. 2012). Given that raptors have long generation times and low reproductive output, additive mortality may prove harmful to population persistence (Drewitt and Langston 2006). Furthermore, the indirect effects produced by displacement, habitat loss or barriers to movements, difficult to assess in conjunction with direct mortality due to observational limitations, may lead to negative changes in survival and breeding success (Masden et al. 2010).

Site selection and strategic planning are critical to avoid or minimise undesirable impacts of wind energy on birdlife (Drewitt and Langston 2006). At the landscape scale, mapping avian distribution or space use allows the identification of areas containing vulnerable species, priority habitats or major flight paths (Hayes et al. 2015), providing guidance to developers 
46 early in the planning stage (see Bright et al., 2008; Fargione et al., 2012; Fielding et al., 2006;

47 Miller et al., 2014). Early locational guidance, though not a substitute for Environmental

48 Impact Assessment (EIA), may enable developments to be sited where risk of conflict is

49 presumably lower.

50 Wind energy is an integral part of Finland's National Energy and Climate Strategy, with a

51 goal to supply 8TWh of wind-derived electricity by 2030 (National Energy and Climate

52 Strategy, 2016). In 2016, an installed capacity of $c a$. $1500 \mathrm{MW}$ accounted for 3.5\% (3 TWh)

53 of the country's electricity consumption (Finnish Energy Industries, 2017). In 2011, a new

54 Finnish Wind Atlas was produced to facilitate site selection by providing estimates of wind-

55 energy potential (Tammelin et al. 2011). The Finnish Wind Atlas identified a 30-km wide

56 coastal strip (including an extension to offshore zones), highlands, large lakes and fields as the

57 most favourable areas for electricity generation. The coastal-offshore strip is the largest of such

58 areas and contains most of the existing wind farms and development proposals (Finnish Wind

59 Power Association, 2016). Coastal areas encompass a large extent of the white-tailed eagle

60 (Haliaeetus albicilla) range in Finland, supporting an estimated $80-90 \%$ of its breeding

61 population (Herrmann et al. 2011).

62 The white-tailed eagle is classified as a vulnerable species in the Finnish Red List (Tiainen

63 et al. 2016), and is listed in Annex I of the EU's Birds Directive (Directive 2009/147/EC, 2009).

64 The species can be negatively affected by wind farms. On the Norwegian island of Smøla,

65 collision mortality and displacement of breeding pairs have been associated with a reduction

66 in breeding success (Bevanger et al., 2010; Dahl et al., 2012). Collisions have also been

67 reported in Germany (Krone and Scharnweber 2003), Poland (Zieliński et al. 2011), and Japan

68 (Ueta et al. 2010), adding to the mortality attributed to other anthropogenic causes (e.g. lead

69 poisoning; Krone et al., 2003). In Finland, white-tailed eagles appear to be more likely to breed 
70 successfully when their territory is located farther from a facility (F. Balotari-Chiebao et al. 71 2016).

72 Adult white-tailed eagles of the Western Palaearctic are typically sedentary (Hardey et al. 73 2013), though breeding adults from e.g. inland territories in Northern Europe winter on the 74 Baltic Sea coast; (Forsman 1999). Young birds disperse during their first years of life and may 75 cover long distances before reaching maturity (ca. 5 yr.; Hardey et al. 2013). Bevanger et al. 76 (2010) reported that juveniles from Smøla moved extensively along the coast of Norway,

77 following a seasonal pattern in their return to the natal sites. Little is known of the dispersal 78 movements of Finnish white-tailed eagles, especially in relation to wind energy. Here, we use 79 long-term satellite telemetry data (1) to report on the large-scale movements of pre-breeding 80 white-tailed eagles with a special reference to wind energy. In particular, we assess their space 81 use in relation to site-specific annual power production potential (GWh), a relevant measure 82 for wind-energy developers. Also, we (2) assess their space use against the spatial distribution 83 of existing and recently proposed wind farms. Based on these two objectives, we provide 84 information to developers and planning authorities on how to better consider the species in the 85 planning process. 


\section{Materials and methods}

\subsection{Study species and turbine-related mortality}

The white-tailed eagle is a diurnal raptor that breeds along sea coasts and by large rivers, lakes and reservoirs, feeding primarily on fish and waterfowl (Cramp and Simmons 1980). In Finland, despite being widely distributed, the species breeds in three main areas: the Archipelago Sea, the Quark, and Lapland (Stjernberg et al. 2005). In 2016, nearly 400 occupied territories were confirmed (Stjernberg et al. 2016). White-tailed eagles are exposed to direct mortality due to collision with wind turbines. In Finland, at least 10 fatalities have been reported based on opportunistic observations made by the general public (T. Stjernberg, personal communication, December 8, 2016). While this figure appears negligible, it underestimates the true impact of Finnish facilities, because a reliable estimate of turbinerelated mortality requires systematic carcass searches (Smallwood 2007).

\subsection{Satellite telemetry}

A total of 14 nestlings were outfitted with a backpack-style $70 \mathrm{~g}$ Argos/GPS Solar Powered PTT (Platform Transmitter Terminal; Microwave Telemetry, Inc.) in 2009-2011 and 2013 (Fig. 1; Table 1). The PTT weighed $c a .100 \mathrm{~g}$ with an additional battery for data collection during winter. The total weight carried by an eagle was in accordance with recommendations on loading (Kenward 2001). The devices were programmed to transmit on an hourly basis mostly during daytime. Besides georeferenced points, the data included instantaneous speed, altitude, and course over ground. Maps and descriptions of individual movements are available at the website of the Finnish Museum of Natural History: http://www.luomus.fi/en/finnish-whitetailed-sea-eagles-satellite-tracking.

Since we were interested in studying white-tailed eagle movements at the landscape scale, we excluded GPS positions collected prior to the dispersal from the natal sites. In the pre- 
111 dispersal period, the home range is characterised by a relatively small area around the nest

112 (Balotari-Chiebao et al. 2016), and this restricted mobility would have caused bias due to

113 location aggregation. Here, an eagle was considered to have dispersed when it stayed $\geq 5 \mathrm{~km}$

114 from the nest for at least 10 consecutive days. By the time the last observations were received

115 (November 2015), none of the eagles had started breeding. Ringing and satellite tagging were

116 conducted with permission from a local environmental authority, the Centre for Economic

117 Development, Transport and the Environment (ELY).

\subsection{Study area and explanatory variables}

120 We divided Finland into a grid of 5 x $5 \mathrm{~km}$ cells based on the Finnish Wind Atlas. Our response

121 variable was the total number of eagle positions per cell. We applied the so-called queen's case

122 to map areas of occurrence of the dispersing eagles, consisting of neighbouring cells with at

123 least one position. The queen's case considers all eight neighbours of a focal cell for common

124 boundary. Our aim was to compare the occurrence areas to identify and focus the analysis on

125 a representative area within Finland, given our sampling constraints in terms of origin (limited

126 distribution) and number of study eagles.

127 Based on the ecology of the species, we selected five explanatory variables that may

128 influence its space use at the landscape scale. We calculated the Euclidean distance between

129 the cell centroids and three landscape features: (1) the Baltic Sea, (2) the nearest waterbody

130 (here, a river or a lake $>9 \mathrm{~km}^{2}$ ), and (3) the natal nests. We included the sea and other

131 waterbodies to account for the fact that the white-tailed eagle lives near open water. Similarly,

132 the natal nests can be expected to have an influence on dispersal patterns (Bevanger et al. 2010).

133 Since the data were analysed at the population level, we derived for each cell a single value to

134 represent the multiple nests. To this end, we used the arithmetic mean: $\frac{1}{n} \sum_{i=1}^{n} d_{i}$, where $d_{i}$ is

135 the distance between a focal cell and the ith nest and $n$ is the total number of nests. To 
136 characterise the cells in terms of human infrastructure and natural habitats, we calculated the 137 percentage of all (4) artificial surfaces and (5) forests and semi-natural areas (hereafter forests),

138 respectively. Forests are used here as a measure of natural habitats due to their importance to 139 white-tailed eagles within this latitudinal range (Helander and Stjernberg 2002). We used the 140 open-source CORINE Land Cover 2012 (20-m resolution) to obtain all the above variables.

141 To specifically address the question of wind energy, we used the Finnish Wind Atlas to 142 extract an additional variable. The Finnish Wind Atlas provides a number of wind energy143 related estimates, including potential power production (MWh) for turbines with a different 144 nominal capacity (1MW, 3MW, and 5MW) at various heights above ground level. We selected 145 (6) the estimated average annual production potential of a 3MW turbine with a hub height at $146150 \mathrm{~m}$ above ground level $(2.5-\mathrm{km}$ resolution). Turbines with this nominal capacity are 147 nowadays commonly proposed in Finland (Supporting Information).

\subsection{Risk assessment}

150 We assessed the space use of the dispersing eagles in relation to the spatial distribution of wind151 energy development, with the aim to detect a potential human-wildlife conflict at the landscape scale. We derived a binomial variable (hereafter wind-farm presence) by identifying the cells that contained (coded as 1) or did not contain an existing or proposed facility (coded as 0 ). We

154 then tested (see below) whether the facility-containing cells were selected or avoided by the 155 eagles. Furthermore, we applied a $t$-test to compare the power production potential between 156 cells with and without a facility. This comparison would indicate whether the cells so far 157 selected for development have actually a greater potential.

158 We obtained the coordinates of existing turbines via a high-resolution map by the National 159 Land Survey of Finland. Information on the proposed wind farms was supplied by the Finnish 160 Wind Power Association (FWPA, Supporting Information). The supplied material contained 
161 specifications such as project phase, number of turbines, nominal capacity and estimated 162 location of wind farms proposed for 2016-2020. Project phase refers to the stage in the planning 163 and development process, ranging from proposal (Phase 0) to operation (Phase 8). The 164 accuracy of locations typically increases as the project moves forward (FWPA, personal 165 communication, April 20, 2016). Only proposals from Phase 3 and above (i.e. with at least an 166 Environment Impact Assessment [EIA] under process) were considered for analysis (Table 2).

167 Data were carefully checked for duplicate information.

168 We calculated flight heights by subtracting the ground elevation from the altitude 169 determined by the PTT. Ground elevation was estimated using the 30-m resolution Advanced 170 Spaceborne Thermal Emission Radiometer (ASTER GDEM 2, a product of METI and NASA).

171 Briefly, flight height estimation is influenced by GPS accuracy $( \pm 18 \mathrm{~m}$, according to 172 manufacturer), elevation data accuracy ( $\pm 8.68 \mathrm{~m}$ for ASTER GDEM 2;(Gesch et al. 2012), 173 and the interpolation between the two datasets $(30 \mathrm{~m}$, reflecting the elevation data 174 resolution;(Katzner et al. 2012). Combing these sources of error, the accuracy of our estimates 175 is $\pm 57 \mathrm{~m}$. We computed mean flight height over the sea and over land, and the proportion of 176 in-flight positions that occurred within a rotor-swept zone of 50-200 $\mathrm{m}$ above ground level.

2.5 Data analyses

179 We used a Generalised Additive Mixed Model (GAMM) to study the relationship between 180 number of eagle positions (response variable) and explanatory variables, including wind-farm 181 presence for the risk assessment. We chose the negative binomial distribution to account for 182 the overdispersion in the data, as the variance was considerably larger than the mean. We built 183 a correlation matrix with all possible combinations of the variables to assess collinearity with 184 Spearman's correlation coefficient. GAMMs are sensitive to the inclusion of highly correlated 185 variables (Zuur et al. 2009). Because the cells closer to each other had a more similar number 
186 of eagle positions than those farther apart (Fig. S1), we added to the model a spatial correlation structure.

188 The number of observations per individual varied greatly due to differences in tracking time

189 (Table 1). To check whether the use of unequal sample sizes produced bias, we repeated the 190 analysis based on a time period that was available for most birds, considering only first-year 191 observations after dispersal $(\overline{\mathrm{x}}=2529$ positions $\pm 791 \mathrm{SD} ; n=14)$. Data analysis and graphical 192 displays were performed in R 3.3.0 (R Core Team, 2016), with packages sp (Pebesma and 193 Bivand 2005), rgeos (Bivand et al. 2013; Bivand and Rundel 2016), mgcv (Wood 2011), and 194 raster (Hijmans 2016). MapInfo Professional 12.0 was used to produce Figure 1.

\section{Results}

197 The eagles were tracked for 75-2239 days after leaving the natal sites, which amounted to 83389 positions (73\%) from Finland and 30381 positions (27\%) from other Baltic Sea

199 countries. The latter were excluded from all calculations, because we did not have equivalent 200 information for other countries. By the end of the study period, four eagles had died from 201 unknown causes. Details of the movement data for each eagle are provided in Table 1. We compiled 94 operational (1-22 turbines/site) and 229 proposed wind farms (1-90 turbines/site).

203 Of these, 310 were onshore and distributed mostly in coastal areas, notably in Satakunta, 204 Ostrobothnia, Central Ostrobothnia, and Northern Ostrobothnia (Fig. 2); these are all regions 205 facing the Gulf of Bothnia. Thirteen facilities were offshore.

\subsection{Space use}

208 The dispersing eagles wandered widely across Finland, visiting regions considerably far from 209 the nests, such as North Karelia and Lapland (Fig. 3). However, they occurred primarily and 210 were most often located along the coast and nearby areas. This is indicated by the largest area 
211 of occurrence (totalling 2984 cells), which encompassed nearly the whole coastline and

212 contained alone $>87 \%$ of all positions. Much smaller occurrence areas were seen in northern

213 Lapland (Fig 3). There was considerable overlapping of individual space use, especially in

214 parts of Ostrobothnia, where up to nine eagles used the same cells at different times (Fig. 3).

215 Given the representativeness of the largest area of occurrence, in terms of both size and

216 relocation frequency, we restricted the analysis and risk assessment to that area. With a large

217 coastal range, this area included grid cells with widely varying proportions of waterbodies and

218 land surface. To test the influence on cell use of our two habitat variables, artificial surfaces

219 and forests, we had to avoid the inclusion of cells with little or without land surface. We

220 therefore created two sets of data for two separate analyses, one (1) for all cells and another (2)

221 only for cells with $\geq 50 \%$ of land surface. The habitat variables were only analysed with the 222 latter dataset.

223

2243.2 Explanatory variables: collinearity and relationship with eagle movements

225 A correlation matrix revealed that power production potential was highly correlated $(>|0.7|)$

226 with sea distance and waterbody distance. This is because wind energy has greater potential

227 towards the sea, and generally lower potential towards lakes and rivers owing to their 228 distribution in relation to the coastline. Given the general aims of this study, we retained power 229 production potential and excluded the other two variables (separate model output is available 230 for sea distance and waterbody distance as supplementary material; Tables S1 and S2).

231 Differences in tracking time did not significantly influence the results (Table S3); hence, we 232 present here only the results based on all observations. 
235 We found the space use of the dispersing eagles to be strongly associated with power 236 production potential, as grid cell use increased sharply with an increase in the potential for

237 power production (Table 3). However, this association was not linear. It humped around a 238 power production potential of $50 \mathrm{GWh}$, reflecting the decreasing use of the more distant 239 offshore cells, the cells with greatest potential (Fig. 4a). We also found that the eagles tended 240 to be located in areas closer to the nests (Table 3).

\subsubsection{Analysis on cells with $\geq 50 \%$ of land surface}

243 When considering only cells with at least $50 \%$ of land surface, a large proportion of offshore

244 cells were excluded from analysis. Hence, this time, grid cell use increased with increasing 245 power production potential in a linear fashion (Fig. 4b). Similar to the previous analysis, areas 246 closer to the nests were used more frequently than areas farther away. The cells where the 247 eagles occurred had much more forests $(\overline{\mathrm{x}}=45.6 \% \pm 31.1 \mathrm{SD})$ than artificial surfaces $(\overline{\mathrm{x}}=3.7 \%$ $248 \pm 5.6 \mathrm{SD}$ ). Despite their generally low surface area, there was a sharp decrease in the use of 249 cells with increasing amounts of artificial surfaces, such as urban fabric and industrial units 250 (Fig. 4b). No similar relationship was detected with forest areas.

\subsection{Risk assessment}

253 A total of 185 of 2984 cells were found to contain an existing or proposed wind farm, of which 254156 were visited by at least one eagle $(\overline{\mathrm{x}}=31$ positions $\pm 102 \mathrm{SD})$. Despite this high degree of co-occurrence (Fig. 5), the use of cells with a facility was not greater than that of cells without a facility (Table 3). In terms of power production potential, cells with a facility had a lower potential $(\overline{\mathrm{x}}=39.9 \mathrm{GWh} \pm 7.9 \mathrm{SD})$ compared to the cells without a facility $(\overline{\mathrm{x}}=41.0 \mathrm{GWh} \pm$

$25810.8 \mathrm{SD}$ ). This indicates that wind-energy development has not targeted cells with greatest potential for electricity production $(t=3.498 ; \mathrm{df}=233.75 ; p=<0.001)$. 
260 Eagles flew at low to intermediate elevations over the sea $(\overline{\mathrm{x}}=90 \mathrm{~m} \pm 151 \mathrm{SD})$ and land $(\overline{\mathrm{x}}$

$261=198 \mathrm{~m} \pm 209 \mathrm{SD})$. A considerable proportion of over-sea $(21 \%)$ and over-land flights $(37 \%)$

262 were at a rotor-swept zone of 50-200 m. Around 43\% of all flights occurred within $50 \mathrm{~m}$ above 263 ground level.

\section{4. Discussion}

266 We used satellite telemetry to study the space use of white-tailed eagles during their several

267 years long dispersal phase, focusing on a potential conflict with wind-energy development in

268 Finland. Despite visiting a large proportion of the country, we showed that the eagles stayed

269 primarily along the coast and nearby areas. More inland and distant offshore areas were used

270 to a lesser extent. Because of the distribution of wind resources, the most frequently used areas

271 by the eagles contained considerable potential for power production. However, the areas with

272 an existing or proposed wind farm did not appear to have a higher-than-average eagle

273 relocation frequency, suggesting that their site selection would not pose an elevated threat to

274 dispersing eagles. Altogether, our results suggest that there are ways for achieving the 2030

275 national goal on wind energy without elevating the threat to dispersing white-tailed eagles

276 (National Energy and Climate Strategy, 2016).

277 The strong positive correlation between the number of eagle positions and the potential for

278 power production indicates a potential conflict with wind-energy development. However, the

279 existing and recently proposed wind farms appeared not occur in areas used more by the eagles

280 than other areas, though there are specific locations that merit a careful examination. For example, the island of Raippaluoto, part of the Kvarken Archipelago, holds a proposal with 9-

28236 turbines (Phase 4: EIA approved). The grid cell proposed for construction was visited by 283 eight eagles (three of which coming from far-away nests: 200-340 km) and its surroundings

284 were among the most used in the whole country. Thus, while cell use was not greater in the 
285 facility-containing cells, we caution against interpreting this finding as evidence for no 286 potential impact at any given site. Our estimates suggest that the eagles were mainly flying at 287 low altitudes over the sea and land and within a rotor-swept zone of 50-200 m, thus being at 288 risk from onshore and offshore turbines depending on site selection.

289 Grid cells occupied by the eagles had a very low percentage of artificial surfaces, which in 290 our study area consisted mainly of urban fabric and industrial and commercial units. This 291 reflects the broader Finnish landscape, dominated by forests and waterbodies. We nevertheless 292 showed that the greater the percentage of artificial surfaces, the lower the number of eagle 293 positions. This pattern likely results from a combined effect of a lack of suitable habitats or 294 feeding grounds in areas partially covered by human infrastructure, and the disturbance caused 295 by human activities. In addition, as expected, cells closer to the nests were used more frequently than cells farther away, reflecting the tendency for the eagles to return to the natal areas

297 (Bevanger et al. 2010).

298 Wind-energy development in Finland has targeted cells that, compared to non-targeted 299 cells, had a lower power production potential. This is partly explained by a bias against 300 development in offshore zones. According to our compilation, only 13 wind farms have been built or proposed offshore. Naturally, it should not be assumed that all of the remaining cells would actually be viable or available for turbine installation, a process which is subject to technical, environmental and social constraints (Aydin et al. 2010). The summed capacity of

304 Finland's proposed wind farms greatly exceeds what would be required to reach the national 305 goal for 2030. More specifically, $c a .25 \%$ of the proposed capacity would be sufficient. Based on the estimated area of a wind-farm project, Zakeri et al. (2015) calculated that the installation of a 2-MW turbine requires $1.5 \mathrm{~km}^{2}$ or $75 \mathrm{ha} / \mathrm{MW}$ (including an area not directly disturbed by the installation). If these estimates are representative, the installed capacity expected for 2030 would claim ca. $2335 \mathrm{~km}^{2}$ (or $0.7 \%$ of the national land area). Tosh et al. (2014) noted that a 
310 turbine location is likely more influential than its specifications. Site selection is crucial to

311 reduce the risk of collision with white-tailed eagles, as they may lack a behavioural response

312 to avoid a wind farm overlapping with important habitats (see Dahl et al., 2013). We showed

313 that considerable wind resources are found outside the areas most used by the eagles. In cases

314 of overlap with proposed facilities, it appears possible to obtain an equivalent output by

315 building in alternative sites.

316 Our study was developed with the use of long-term and high-precision data, comprising the

317 best information currently available. However, a number of caveats in the study design and 318 data collection inevitably limit its application. Our study eagles came from two of the three 319 major breeding areas for white-tailed eagles in Finland, i.e. the Archipelago Sea and the Quark,

320 but they did not include Lapland. We found that as many as six eagles (from nests hundreds of 321 kilometres away) visited sites in Lapland, suggesting the presence of important habitats for 322 dispersing eagles. Lapland contained 13 existing and 18 proposed wind farms, and although no 323 overlap was detected, additional data from eagles specifically from Lapland are needed for 324 further investigation. Another source of limitation was the sample size of eagles, which was 325 relatively small (14 individuals) due to the costs involved with satellite tagging. Also, the 326 Kvarken Archipelago contained alone a third of the eagles. Given these limitations, our 327 decision to restrict the analysis and risk assessment to the largest occurrence area may have 328 helped us reduce the risk of erroneously drawing more general conclusions.

329 The freely-available Finnish Wind Atlas gave us a unique opportunity to study eagle space 330 use in relation to a variable which is of relevance to wind energy, namely power production 331 potential. Whenever available, its application may contribute to the study of birdlife-wind 332 energy interactions. In view of an expanding wind industry, further research is needed to 333 provide support for careful site selection and strategic planning, widely recognised as critical 
334 steps to avoid or minimise undesirable impacts on avian populations (Drewitt and Langston 335 2006).

\section{Conclusions}

338 The main areas used by pre-breeding white-tailed eagles during the dispersal period contained

339 considerable potential for wind-energy generation. In different numbers and frequency, the

340 eagles visited most of the areas with an existing or recently proposed wind farm. However,

341 such areas did not appear to have a higher-than-average relocation frequency, suggesting that

342 their site selection would not pose an elevated threat to dispersing eagles. Nevertheless, it

343 should not be concluded that co-occurrence poses no threat to individual eagles at any given

344 site. Available wind resources suggest that careful site selection may ensure the achievement

345 of the 2030 national goal on wind energy without elevating the potential threat to dispersing

346 white-tailed eagles. 
References

Aydin, N.Y., Kentel, E. \& Duzgun, S. (2010). GIS-based environmental assessment of wind energy systems for spatial planning: A case study from Western Turkey. Renew. Sustain. Energy Rev. 14, 364-373.

Balotari-Chiebao, F., Brommer, J.E., Niinimäki, T. \& Laaksonen, T. (2016a). Proximity to wind-power plants reduces the breeding success of the white-tailed eagle. Anim. Conserv. 265-272.

Balotari-Chiebao, F., Villers, A., Ijäs, A., Ovaskainen, O., Repka, S. \& Laaksonen, T. (2016b). Post-fledging movements of white-tailed eagles: Conservation implications for windenergy development. AMBIO J. Hum. Environ.

Bevanger, K., Berntsen, F., Clausen, S., Dahl, E.L., Flagstad, Ø., Follestad, A., Halley, D., Hanssen, F., Johnsen, L., Kvaløy, P., Lund-Hoel, P., May, R., Nygård, T., Pedersen, H.C., Reitan, O., Røskaft, E., Steinheim, Y., Stokke, B. \& Vang, R. (2010). Pre- and post-construction studies of conflicts between birds and wind turbines in coastal Norway (Bird-Wind) ( No. 620). , NINA Report. Trondheim, Norway.

Bivand, R. \& Rundel, C. (2016). rgeos: Interface to Geometry Engine - Open Source (GEOS). Bivand, R.S., Pebesma, E. \& Gomez-Rubio, V. (2013). Applied spatial data analysis with R. 2nd edn. New York, USA: Springer.

Bright, J., Langston, R., Bullman, R., Evans, R., Gardner, S. \& Pearce-Higgins, J. (2008). Map of bird sensitivities to wind farms in Scotland: A tool to aid planning and conservation. Biol. Conserv. 141, 2342-2356.

Cramp, S. \& Simmons, K.E.L. (1980). Handbook of the Birds of Europe, the Middle East and North Africa: Hawks to Bustards. Oxford, UK: Oxford University Press.

Dahl, E.L., Bevanger, K., Nygård, T., Røskaft, E. \& Stokke, B.G. (2012). Reduced breeding success in white-tailed eagles at Smøla windfarm, western Norway, is caused by mortality and displacement. Biol. Conserv. 145, 79-85.

Dahl, E.L., May, R., Hoel, P.L., Bevanger, K., Pedersen, H.C., Røskaft, E. \& Stokke, B.G. (2013). White-tailed eagles (Haliaeetus albicilla) at the Smøla wind-power plant, Central Norway, lack behavioral flight responses to wind turbines. Wildl. Soc. Bull. 37 , $66-74$.

Directive 2009/147/EC. (2009). DIRECTIVE 2009/147/EC of the European Parliament and of the Council on the conservation of wild birds.

Drewitt, A.L. \& Langston, R.H.W. (2006). Assessing the impacts of wind farms on birds. Ibis $148,29-42$.

Erickson, W.P., Johnson, G.D. \& Young, D.P.J. (2005). A summary and comparison of bird mortality from anthropogenic causes with an emphasis on collisions. , In: Ralph, C. John; Rich, Terrell D., editors 2005. Bird Conservation Implementation and Integration in the Americas: Proceedings of the Third International Partners in Flight Conference. 2002 March 20-24; Asilomar, California, Volume 2 Gen. Tech. Rep. PSW-GTR-191. Albany, CA: U.S. Dept. of Agriculture, Forest Service, Pacific Southwest Research Station: p. 1029-1042.

Fargione, J., Kiesecker, J., Slaats, M.J. \& Olimb, S. (2012). Wind and Wildlife in the Northern Great Plains: Identifying Low-Impact Areas for Wind Development. PLOS ONE 7, e41468.

Fielding, A.H., Whitfield, D.P. \& McLeod, D.R.A. (2006). Spatial association as an indicator of the potential for future interactions between wind energy developments and golden eagles Aquila chrysaetos in Scotland. Biol. Conserv. 131, 359-369. 
Finnish Energy Industries. (2017). Tuulivoima [WWW Document]. URL https://energia.fi/en/current_issues_and_material_bank/material_bank/energy_year_2 016_electricity_increase_in_electricity_consumption.html

Finnish Wind Power Association. (2016). Tuulivoimalaitokset ja tuulivoimahankkeet Suomessa [WWW Document]. URL http://www.tuulivoimayhdistys.fi/

Forsman, D. (1999). The Raptors of Europe and the Middle East: A Handbook of Field Identification. London: T \& A. D. Poyser.

Gesch, D.B., Oimoen, M.J., Zhang, Z., Meyer, D.J. \& Danielson, J.J. (2012). Validation of the ASTER Global Digital Elevation Model Version 2 over the conterminous United States. In : 281-286. Presented at the Imaging a sustainable future, 22nd Congress.

Global Wind Energy Council. (2015). Global Wind Report: Annual Market Update.

Hardey, J., Crick, H., Wernham, C., Riley, H., Etheridge, B. \& Thompson, D. (2013). Raptors: a field guide to survey and monitoring. Norfolk: TSO (The Stationery Office).

Hayes, G., Gove, B. \& Whitaker, S. (2015). Avoiding ecological "constraints" in wind energy. In IAIA15 Conference Proceedings. Presented at the 35th Annual Conference of the International Association for Impact Assessment, Florence, Italy.

Herrmann, C., Krone, O., Stjernberg, T. \& Helander, B. (2011). Population Development of Baltic Bird Species: White-tailed Sea Eagle (Haliaeetus albicilla) (Helsinki Commission - Nature Protection and Biodiversity Group). , HELCOM Indicator Fact Sheet. Kotka, Finland.

Hijmans, R.J. (2016). raster: Geographic Data Analysis and Modeling.

Katzner, T.E., Brandes, D., Miller, T., Lanzone, M., Maisonneuve, C., Tremblay, J.A., Mulvihill, R. \& Merovich, G.T. (2012). Topography drives migratory flight altitude of golden eagles: implications for on-shore wind energy development. J. Appl. Ecol. 49, $1178-1186$.

Kenward, R.E. (2001). A manual for wildlife radio tagging. London: Academic Press.

Krewitt, W. \& Nitsch, J. (2003). The potential for electricity generation from on-shore wind energy under the constraints of nature conservation: a case study for two regions in Germany. Renew. Energy 28, 1645-1655.

Krone, O., Langgemach, T., Sömmer, P. \& Kenntner, N. (2003). Causes of mortality in whitetailed sea eagles from Germany. In Proceedings of the Swedish Society for Nature Conservation: 211-218. Helander, B., Marquiss, M. \& Bowerman, W. (Eds). . Presented at the Sea Eagle 2000, Stockholm, Sweden.

Krone, O. \& Scharnweber, C. (2003). Two white-tailed sea eagles (Haliaeetus albicilla) collide with wind generators in northern Germany. J. Raptor Res. 174.

Loss, S.R. (2016). Avian interactions with energy infrastructure in the context of other anthropogenic threats. The Condor 118, 424-432.

de Lucas, M., Ferrer, M., Bechard, M.J. \& Muñoz, A.R. (2012). Griffon vulture mortality at wind farms in southern Spain: Distribution of fatalities and active mitigation measures. Biol. Conserv. 147, 184-189.

Masden, E.A., Fox, A.D., Furness, R.W., Bullman, R. \& Haydon, D.T. (2010). Cumulative impact assessments and bird/wind farm interactions: Developing a conceptual framework. Environ. Impact Assess. Rev. 30, 1-7.

Miller, T.A., Brooks, R.P., Lanzone, M., Brandes, D., Cooper, J., O’Malley, K., Maisonneuve, C., Tremblay, J., Duerr, A. \& Katzner, T. (2014). Assessing Risk to Birds from Industrial Wind Energy Development via Paired Resource Selection Models. Conserv. Biol. 28, 745-755.

National Energy and Climate Strategy. (2013). National Energy and Climate Strategy (Government Report to Parliament on 20 March 2013).

Pebesma, E.J. \& Bivand, R.S. (2005). Classes and methods for spatial data in R. R News 5. 
$\mathrm{R}$ Core Team. (2016). R: A language and environment for statistical computing. Vienna, Austria: R Foundation for Statistical Computing.

Smallwood, K.S. (2007). Estimating Wind Turbine-Caused Bird Mortality. J. Wildl. Manag. $71,2781-2791$.

Smallwood, K.S. \& Thelander, C. (2008). Bird Mortality in the Altamont Pass Wind Resource Area, California. J. Wildl. Manag. 72, 215-223.

Stjernberg, T., Koivusaari, J., Högmander, J., Ollila, T. \& Ekblom, H. (2005). Population trends and breeding success of the White-tailed Sea Eagle Haliaeetus albicilla in Finland, 1970-2005. In Proceedings of the Workshop on the Status of Raptor Populations in Eastern Fennoscandia. Kostomuksha, Karelia, Russia.

Stjernberg, T., Nuuja, I., Laaksonen, T., Koivusaari, J., Ollila, T., Keränen, S., Ekblom, H., Lokki, H., and Saurola, P. (2016). Population size and nesting success of the Whitetailed Sea eagle in Finland, 2013-2015. Yearbook of the Linnut Magazine. 20-29 (English summary).

Tammelin, B., Vihma, T., Atlaskin, E., Badger, J., Fortelius, C., Gregow, H., Horttanainen, M., Hyvönen, R., Kilpinen, J., Latikka, J., Ljungberg, K., Mortensen, N.G., Niemelä, S., Ruosteenoja, K., Salonen, K., Suomi, I. \& Venäläinen, A. (2011). Production of the Finnish Wind Atlas. Wind Energy 16, 19-35.

Tiainen, J., Mikkola-Roos, M., Below, M., Jukarainen, A., Lehikoinen, A., Lehtiniemi, T., Pessa, J., Rajasärkkä, A., Rintala, J., Sirkiä, P. \& Valkama, J. (2016). Suomen lintujen uhanalaisuus 2015 - The 2015 Red List of Finnish Bird Species. Ympäristöministeriö \& Suomen ympäristökeskus.

Tosh, D.G., Montgomery, W.I. \& Reid, N. (2014). A review of the impacts of onshore wind energy development on biodiversity. , Report prepared by the Natural Heritage Research Partnership (NHRP) between Quercus, Queen's University Belfast and the Northern Ireland Environment Agency (NIEA) for the Research and Development Series No. $14 / 02$.

Ueta, M., Fukuda, Y. \& Takada, R. (2010). Difference in flight behavior between White-tailed and Steller's Sea Eagle in Hokkaido. Bird Res. 6, A43-A52.

Wiser, R., Yang, Z., Hand, M., Hohmeyer, O., Infield, D., Jensen, P.H., Nikolaev, V., O’Malley, M., Sinden, G. \& Zervos, A. (2011). Wind Energy. In IPCC Special Report on Renewable Energy Sources and Climate Change Mitigation. Cambridge, United Kingdom and New York, NY, USA: Cambridge University Press.

Wood, S.N. (2011). Fast stable restricted maximum likelihood and marginal likelihood estimation of semiparametric generalized linear models. J. R. Stat. Soc. Ser. B Stat. Methodol. 73, 3-36.

WWF Finland. (2011). WWF Suomen kanta: Ekologisesti kestävä tuulivoima.

Zakeri, B., Syri, S. \& Rinne, S. (2015). Higher renewable energy integration into the existing energy system of Finland e Is there any maximum limit? Energy 92, 244-259.

Zieliński, P., Bela, G. \& Marchlewski, A. (2011). Report on monitoring of the wind farm impact on birds in the vicinity of Gniezdżewo (gmina Puck, woj. pomorskie). PRO ORNIS, Gdańsk, Poland.

Zuur, A.F., Ieno, E.N., Walker, N.J., Saveliev, A.A. \& Smith, G.M. (2009). Mixed Effects Models and Extensions in Ecology with R. Springer. 
490

491

492

493

494

495

496

497

498

499

500

501

502

503

504

505

506

507

508

509

510

511

512

513

514

515

516

517

518

519

\section{Figures and tables}

Figure 1 Approximate nest locations of the satellite-tagged white-tailed eagles. The dashed circle around the Kvarken Archipelago indicates the area containing five nests which are undiscernible at the used scale due to the short distances between them. The Archipelago Sea is a stronghold of the species in Finland.

Figure 2 National estimates for the production potential of a 3MW turbine installed at $150 \mathrm{~m}$ above ground level, and the locations of the operational and proposed facilities for until 2020 . The original estimates (at a $2.5-\mathrm{km}$ resolution) were adapted to the 5-km resolution used in this study. Region boundaries are depicted. 1: North Karelia; 2: Northern Savonia; 3: Päijänne Tavastia; 4: Southern Savonia; 5: Lapland; 6: Kainuu; 7: Northern Ostrobothnia; 8: Uusimaa; 9: Kymenlaakso; 10: South Karelia; 11: Central Finland; 12: Central Ostrobothnia; 13: Southwest Finland; 14: Ostrobothnia; 15: Pirkanmaa; 16: Satakunta; 17: Southern Ostrobothnia; 18: Tavastia Proper; 19: Åland Islands. Existing $(+)$ and proposed wind farms (o) for until 2020 are also indicated on the map.

Figure 3 Maps of Finland showing the number of positions for fourteen pre-breeding whitetailed eagles and the number of different individuals to have visited a given cell. Values are expressed at a $5-\mathrm{km}$ resolution. Areas of eagle occurrence $>375 \mathrm{~km}^{2}$ are indicated in bold.

Figure 4 Plots showing the effects of smoothed variables on grid cell use in (a) the whole of the largest occurrence area and (b) in cells with at least $50 \%$ of land surface. The boxplot indicates the range, interquartile and mean values for power production potential in the cells containing an existing or proposed facility.

Figure 5 Observed grid cell use by pre-breeding white-tailed eagles in their largest area of occurrence, overlaid by the locations of the existing and $(+)$ proposed wind farms (o) within this area. 


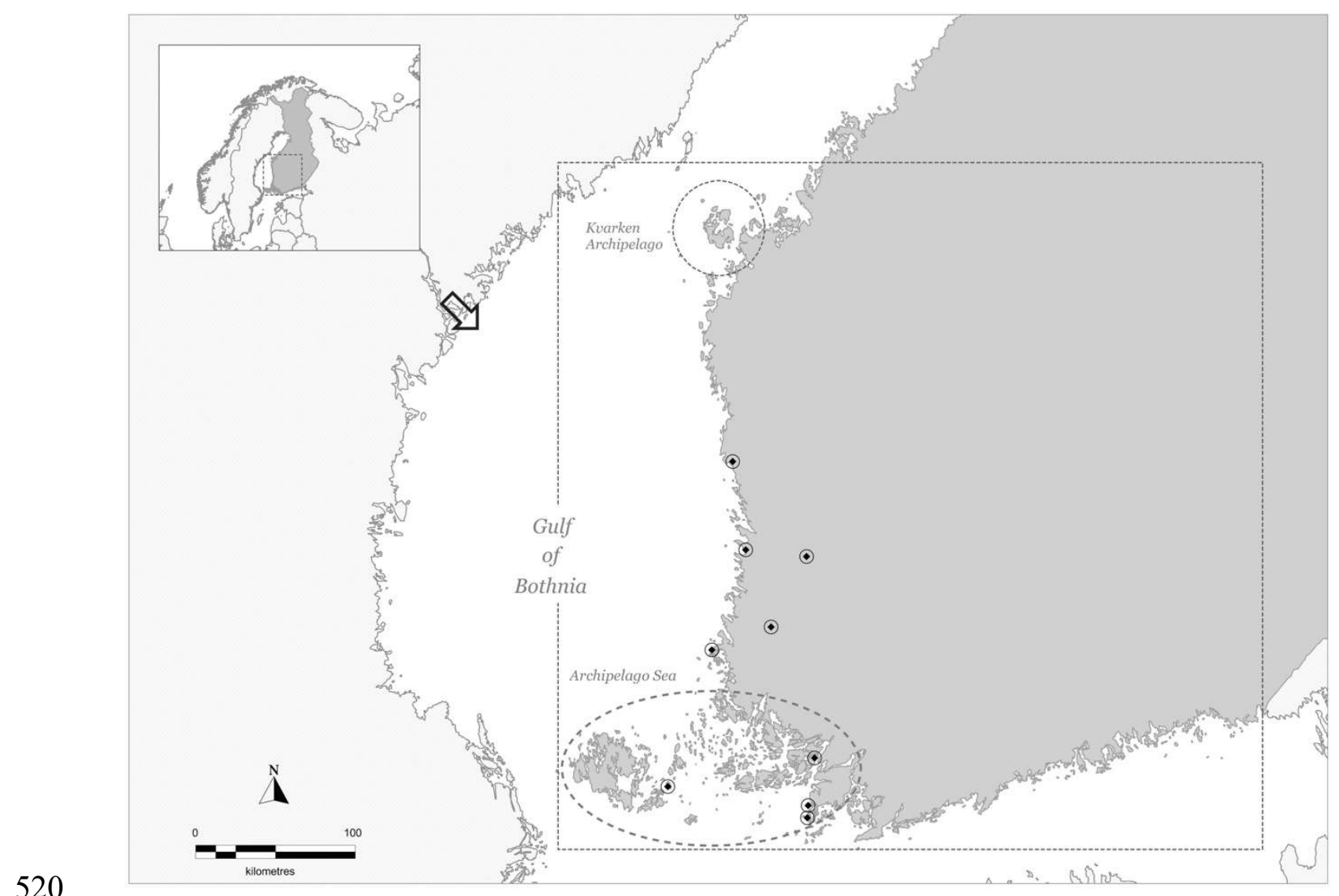

$521 \quad$ Fig. 1 
Prod. potential (GWh)

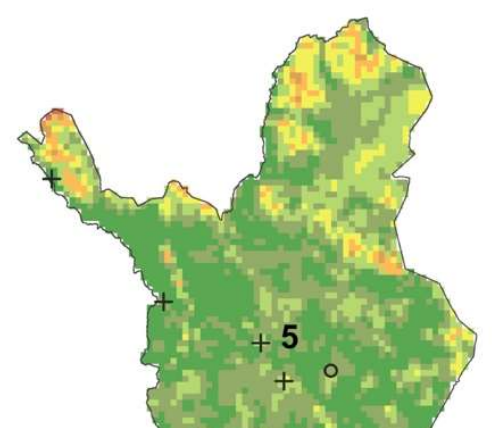
$\square<25$
$\square \quad 25-30$
$\square \quad 30-35$
$\square \quad 35-40$
$\square \quad 40-45$
$\square \quad 45-50$
$\square>50$

523 Fig. 2 

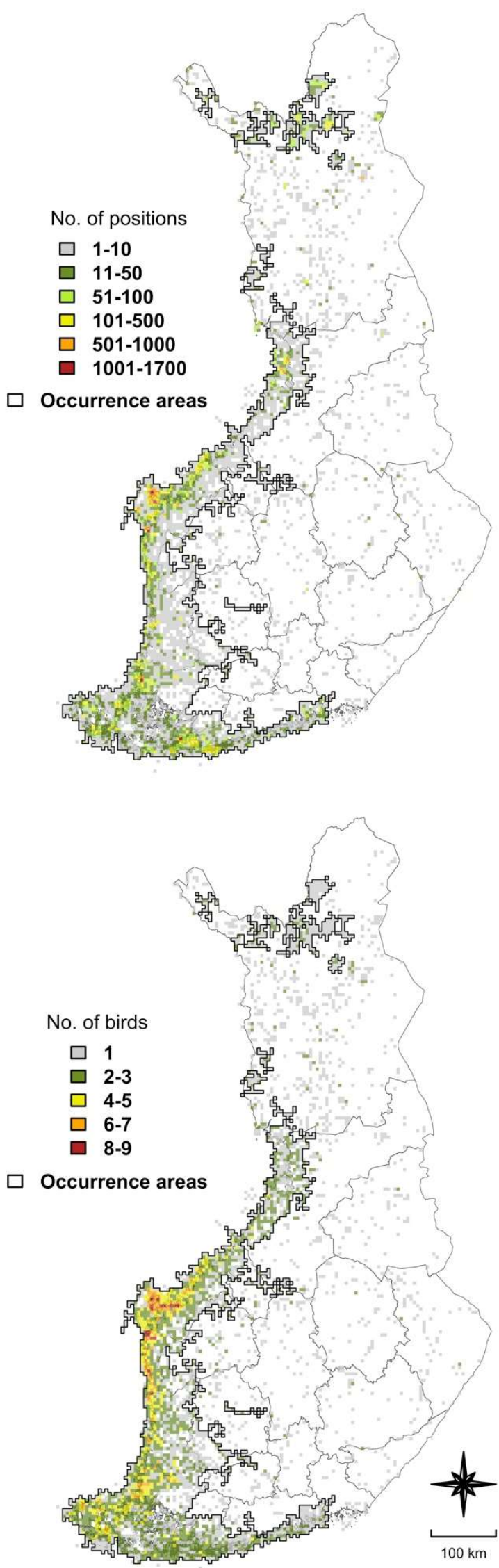

Fig. 3 
a)

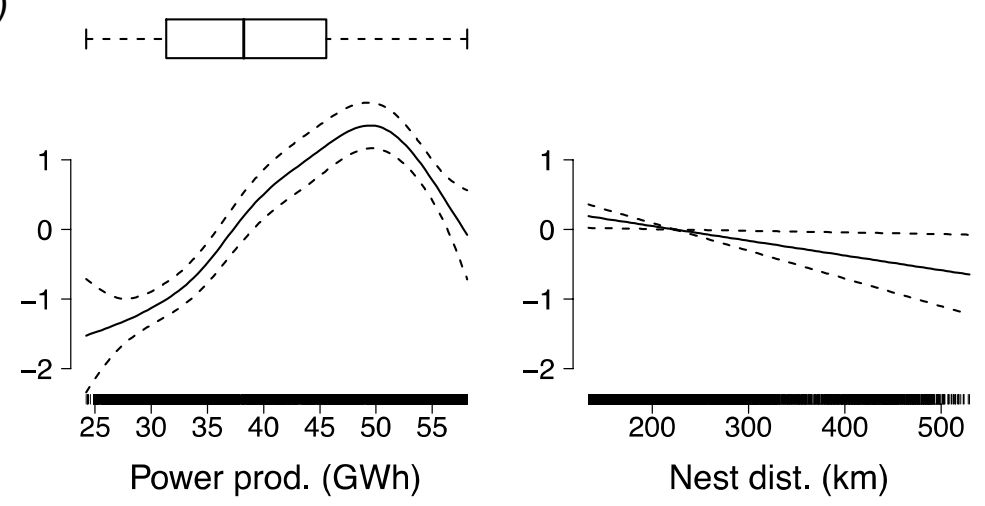

b)
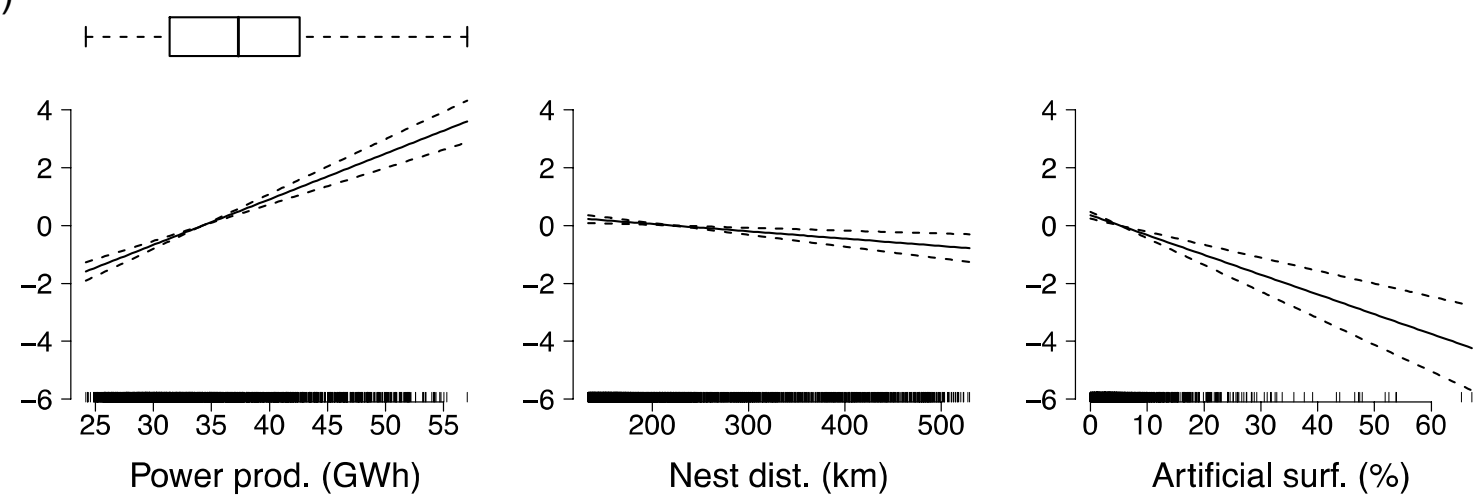

Fig. 4 


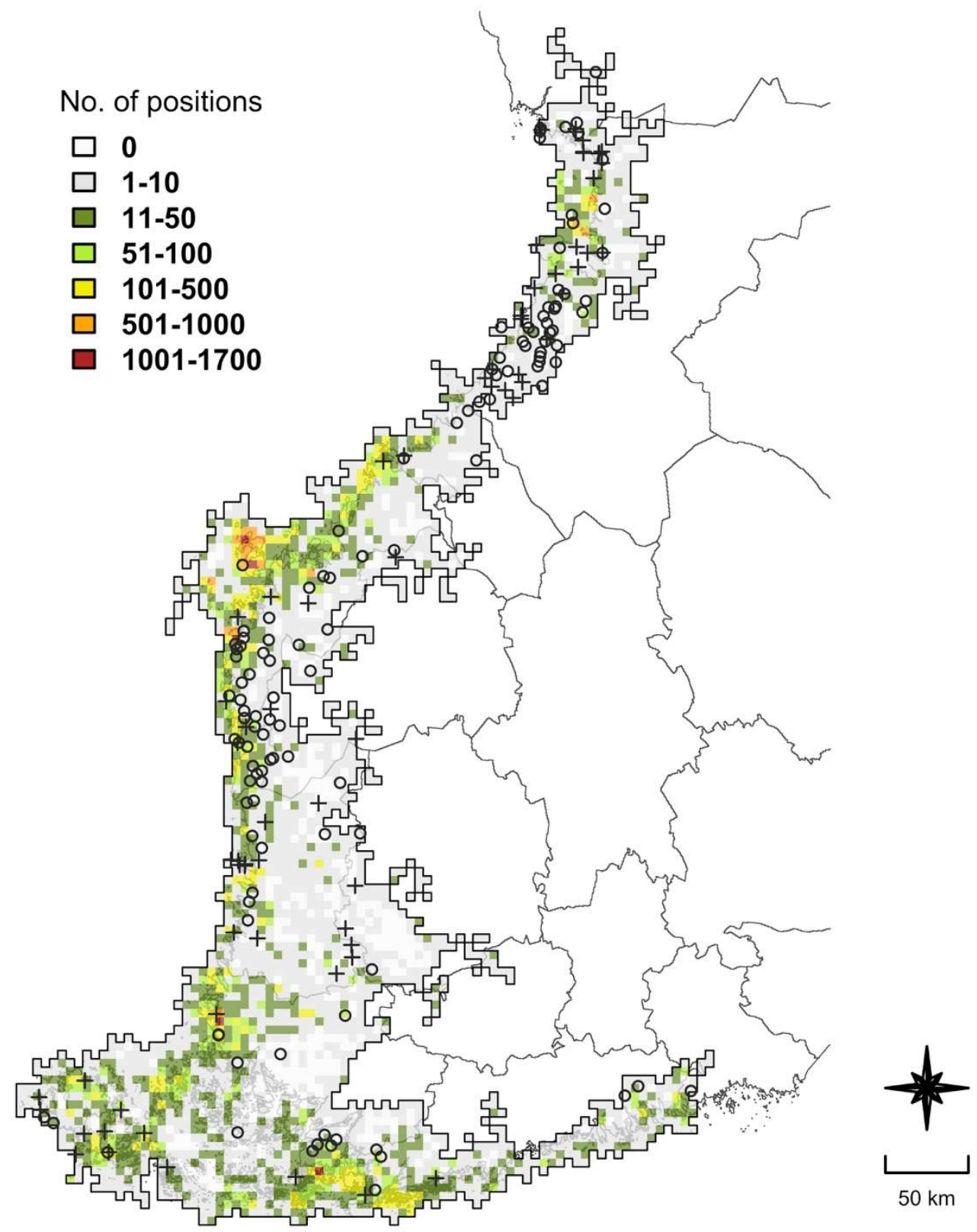

$532 \quad$ Fig. 5 
533 Tables

534

535 Table 1 Details of the long-term telemetry data collected within Finland from 14 satellite536 tagged white-tailed eagles during dispersal. Positions from other Baltic Sea countries were 537 excluded.

538

\begin{tabular}{llll}
\hline Bird ID & $\begin{array}{l}\text { Hatch } \\
\text { year }\end{array}$ & All positions & $\begin{array}{l}\text { In-flight } \\
\text { positions }(\geq \\
5 \mathrm{~m} / \mathrm{s})\end{array}$ \\
\hline 92632 & 2009 & 4093 & 976 \\
92633 & 2009 & 9851 & 259 \\
92634 & 2009 & 15196 & 70 \\
92635 & 2009 & 11399 & 552 \\
33207 & 2010 & 11785 & 638 \\
33210 & 2011 & 2316 & 917 \\
105680 & 2011 & 6790 & 1286 \\
105681 & 2011 & 2548 & 1151 \\
105682 & 2011 & 2901 & 801 \\
33211 & 2013 & 508 & 292 \\
33212 & 2013 & 4781 & 176 \\
105831 & 2013 & 2010 & 210 \\
105832 & 2013 & 4401 & 512 \\
105833 & 2013 & 4810 & 558 \\
& & & \\
\hline Mean \pm SD & & $5956 \pm 4410$ & $600 \pm 382$ \\
\hline
\end{tabular}


541 Table 2 Proposed wind farms for the whole of Finland summarised according to project phase. 542 Proposals refer to the period 2016-2020. It should not be assumed that all projects will be 543 granted approval.

544

\begin{tabular}{llll}
\hline Project phase & Projects & $\begin{array}{l}\text { Minimum } \\
\text { turbine number }\end{array}$ & $\begin{array}{l}\text { Capacity } \\
(\mathrm{MW})\end{array}$ \\
\hline 3 - EIA under process & 27 & 602 & 1809 \\
$\begin{array}{l}\text { 4 - EIA approved/Spatial } \\
\text { planning under process }\end{array}$ & 105 & 1427 & 4315 \\
$\begin{array}{l}\text { 5 - Applying for permits } \\
\text { 6 - Preparing for }\end{array}$ & 50 & 693 & 2172 \\
$\begin{array}{l}\text { construction } \\
7 \text { - Under construction }\end{array}$ & 26 & 247 & 777 \\
\hline Total & 21 & 226 & 670 \\
\hline Mean \pm SD & 229 & 3195 & 9743 \\
\hline
\end{tabular}


546 Table 3 Results of a Generalised Additive Mixed Model (GAMM) examining the space use of 547 dispersing white-tailed eagles in their largest area of occurrence (see Fig. 3). A distinction 548 based on the proportion of land surface is made to evaluate all cells and cells with $\geq 50 \%$ of 549 land surface, with only the latter used to test the influence of artificial surfaces and forests.

550

\begin{tabular}{lllllll}
\hline \multirow{2}{*}{ Dataset } & Variables & \multirow{2}{*}{ Estimate } & t-value & \multicolumn{3}{l}{ Significance of smooth terms } \\
\cline { 5 - 7 } & & & & edf & F-value & P-value \\
\hline \multirow{3}{*}{ All cells } & Power production & - & - & 4.790 & 31.216 & $<0.001$ \\
& Nest distance & - & - & 1.000 & 5.095 & 0.0241 \\
& Wind-farm presence & 0.073 & 0.379 & - & - & 0.705 \\
\hline \multirow{3}{*}{ Cells $\geq 50 \%$} & Power production & - & - & 1.000 & 99.403 & $<0.001$ \\
land use & Artificial surfaces (\%) & - & - & 1.000 & 10.776 & 0.001 \\
& Forests (\%) & - & - & 1.000 & 33.620 & $<0.001$ \\
& Wind-farm presence & -0.003 & -0.018 & - & - & 0.986 \\
\hline
\end{tabular}

